\title{
Tolstoy in Italian Criticism
}

\author{
Maria Volodina \\ Department of Romance Languages \\ Moscow State Institute of International Relations \\ Moscow, Russia
}

\begin{abstract}
The author continues to review Italian critics' vision of the Russian literary great Leo Tolstoy, reflecting upon the problem of perception of his heritage by the Italian literary criticism in the 50-70th of last century. Throughout many decades, in Italy and other countries, the name of Tolstoy, the writer and philosopher, oftentimes has served to buttress quite antagonistic political, moral and aesthetic concepts.
\end{abstract}

Keywords-Tolstoy; Italy; literary criticism; neo-avantgardists

\section{ERIDANO BAZZARELLI}

The work of famous Italian Slavist, belonging to the older generation, Eridano Bazzarelli "How to Read Tolstoy Today" (1970) unveils to our contemporaries the extent of young Italians' keen interest to Tolstoy's novel "War and Peace" at that time.

Right from the assertion about Leo Tolstoy as the "true Russian" author of all times, regardless of his numerous ideas and concepts that had led him away from national problems to universal, global matters, Bazzarelli is accentuating the writer's patriotism. He insists that Tolstoy's patriotism especially manifests itself when it comes to Napoleon Bonaparte, "whose negativity is reinforced by his western heritage" [1]. Bazzarelli gathers that Tolstoy acts as a true Slavophil. "Russia opposes Napoleon, - writes the reviewer, - inasmuch as Napoleon, foreigner and heretic (Catholic), emerged from the perverse Europe to enslave the Orthodox Russian nation." At the same time, Bazzarelli reproaches Tolstoy, who had turned a blind eye on certain historical perspectives that had to be disclosed to Russia in its war with Napoleon. He rebukes Tolstoy for trying not to notice that Holy Russia was then the country with still existing selfdom, where ideas and principles imported from the revolutionizing France, more contemporary and fairer, presented a utopian revery. "Still and all, Tolstoy saw everything and was aware that the Russians, fighting Napoleon, were, altogether, right and wrong, since, by repulsing the foe, they reinforced secular chains of the selfdom." [2]

Such perceptions speak of Bazzarelli's insufficient awareness of historic situation in Russia of the year 1812. The Italian reviewer, apparently, is ready to equate the public sense of Napoleon campaigns in Italy in late $18^{\text {th }}$ century with the liberation war against Napoleon in Russia. The latter hardly had intention to do much good for the Russians and Italians introducing reforms 'a la French revolution'. His invasion in Italy in 1796 evidences the extent of severe hurt to illusions, cherished by most of Italian patriots about Bonaparte's liberation mission in Italy. Bearing personal goals and mission of the French conquest policy in mind, he was ready to employ some parts of Italy's territory as token in game of politics and to sacrifice the values of Italian movement. Breaking Italy's archaic traditions and hereby partly supporting the republican movement, Napoleon hardly cared for Italy's national interests and the victory of republicans as for the creation in the country of such conditions and such political regime that would let France take dominant position on the Apennine peninsular and drain' the country's wealth [3].

\section{EVOLUTION OF TOLSTOY THE WRITER THROUGH ITALIAN REVIEWERS' EYES}

The balance between the artist's life and his work has always been in close focus of Italian researchers. Thus, we find in the monograph by Otto Cuzzer in 1928 the following reasoning on this subject: "Tolstoy wished his life to turn out harmonic, glorious and bright like magnum opus, yet it was much harder to bring this ideal to life."[4]

The article by Silvio Bernardini on Tolstoy and elegance of goodness in 1970, addressing the same topic, gives quite an articulate picture of evolution of Tolstoy's vision of the 'right' living: from pursuit of individual weal to humility, forgiveness, quiet blissfulness of safe conscience.

Describing how young Tolstoy in the pursuit to justify his personal life and human life in general, drafted numerous common standards that would help him turn kind, intelligent, rich, strong, famous and, thus, happy, Bernardini compares this to an attempt to draw over a narrow blanket that covers one part of the body while baring another. Neither wealth nor success of his first works did bring Tolstoy the intrinsic satisfaction, continues Bernardini, the real accomplishment and height of genius were still ahead for the young author, who trusted himself to a host of unrealized plans and unembodied thoughts. Unending search for truth accompanied Tolstoy's creativity.

At its origin, after Tolstoy's first trip abroad in 1857, when the middle-class civilization had uncovered to him its inhumanity and had repelled the writer, Tolstoy felt the need to "step aside" into a world of his sentiment and thoughts, into his own isolated moral and aesthetic canton. In one of his letters addressed to Boris Chicherin in August 1858, Tolstoy writes, "Building of one's own honest little world 
amidst surrounding hoary hideosity and lies is worth something and brings sovereign pleasure." [5] His story "Family Happiness" presents poetization of such honest personal world. Yet the tendency to get into shell at the same time is provoking Tolstoy's inner resistance, "It is strange to recall my believe how it was possible to arrange own happy and fair little world, wherein to live quietly, fail-safe, with no compunction, no disorderliness and do only good, without haste, accurately. Funny! To live fairly one must spoil for, mess around, fight for, commit errors, embark on and give up, and commence again and again, and immortally struggle and lose." [6]

The next period of Tolstoy's evolution the reviewer considers to be the time of his isolated life in the manor Yasnaya Polyana, when the gap between "being" and "appearing", always tormenting Tolstoy, seemed to cease to exist. Before him now appeared a new ideal -getting back to nature - and a new goal - to live with cheerful lightheartedness, like a flower, inside oneself and for oneself, putting off the highborn and humbly accepting the state of things. Bernardini assumes the novel 'War and Peace' presents the triumph of such ideal, calling it 'a hymn to refinement as the only and highest inheritance of Russian nobility." He explains the refinement as a subtle sort of something "ineffable and unreserved that runs in veins of Natasha, Nikolai, old Rostov, the Bolkonskys', whose conduct is absolutely unaffected, easy, natural and therefore aesthetically pleasing." "Just as the sunflower always turns sunwise, so the soul of Tolstoy's heroes is always open to good," marks Bernardini. The aesthetical excuse of their life, accordingly, coincides with the religious justification of it; and, consequently, their grace is good."

The reviewer attempts to explain why Tolstoy's calm and tranquil living could not last longer, "To do so one must live only in complete ignorance, like Nikolai, with one's family, one's land and one's individualism, without writing or looking back at one's spent life and reviewing the present." Such world was not for Tolstoy. Disturbance of the rhythm of unclouded existence in Yasnaya Polyana marked, according to Bernardini, the new period of his life and work-his novel "Anna Karenina", which became, assumes Bernardini, "the result of destruction of the Tolstoyan understanding of the natural existence." "Anna Karenina" presents a somewhat deformed version of "War and Peace", whose feel so to speak thickens, while the characters become vulgar. "In essence, these are the same people, - writes Bernardini, - yet, how they have changed! Anna lacks Natasha's air of lightness, her thrill and emotional outbursts... she is of rotund and heavy frame ..." The reviewer points also to a 'non-elegant' demeanor of Vronsky, which revealed itself in his fault during horse races, when he breaks the back of his favorite. The reviewer remarks that it was not just a mistake, but also an unaesthetic act demonstrative of the rider's weightiness, his lack of rhythm. Vronsky's elegance actually seems false - it is not religion but simple ritual. Moreover, Bernardini draws the conclusion that aristocratism of Anna and Vronsky is fake.

Seemingly, in spite of such interesting and unexpected approach to the problem, this is still an oversimplification of the artist's intention in favor of an abstract ethical and aesthetic conception. As for the succession of Tolstoy's two novels, the central personalities of "Anna Karenina" are of no direct projection of characters presented in "War and Peace". These bonds present the closeness of positions, wherefrom the life opportunities are valued, and the commonness of the author's artistic principles. Just like in "War and Peace", in "Anna Karenina" Tolstoy illustrates the common life flow comprising individual human fortunes. The writer is focused on man's naturality, on the idea of resurgence of the personality ousted from the hypocritical high life.

His disappointment in "the natural lifestyle and the remorse of a rich man of family" evoked by others' sufferings had brought Tolstoy to a new chapter of his moral evolution. He comes to the Christian universal idea like eventual Kingdom of heaven. Inspired by the Gospels, Tolstoy creates the most coherent philosophy of his own, an evolution of a well-developed paradigm born from the writer's thirty-year creativity. "Noble elegances of the aristocracy exist no more for Tolstoy, - writes Bernardini, the middle-class lifestyle he discards as well as absolutely non-aesthetic. The middle-class is piquing itself on its brandished wealth, yet Messieurs' 'elegancy' presents just a refined vulgarity and less obvious superbity, clothed in 'disengagement' and 'easiness'. Simple and pure lifestyle of workpeople - this is what means the true elegancy to Tolstoy. The poor and humble people are humane, because they lack ambition, selfishness - their lives are not in enjoyment of the loads of wealth, but in humble and honest labor and in thankfulness for less. "A pauper, a shoemaker, a peasant, writes Bernardini, - here is the simple and true human being; his attitude to the world lacks controversy between good and beauty, and his life, according to Tolstoy, is esthetically and aesthetically justified." Indeed, Tolstoy's latest works manifested the ideals of moral placability, humbling, universal love and forgiveness, what oftentimes contradicted with the general socio-accusatory framework of his narration.

Meanwhile, Bernardini avoids giving any particular assessment to the mentioned transitions, when it comes to the evolution of Tolstoyan vision of life purpose, yet he links them to certain works, which such transitions resulted in. There is no escaping the impression that the article writer, possessing many historical and literature facts, nonetheless, is inclined to the simplism and to "lining-up" Tolstoy's complex and conflicting quest.

\section{ITALIAN NEO-A VANTGARDISM AND TOLSTOY}

During the 1970s, Tolstoy met the eye of Italian Neoavant-gardism, the purely Italian distinguishing feature of which had been its political radicalism. The avant-gardists demonstrated hostile opinions about the bourgeois civilization, sensing its underlining hazard, namely, turning the culture into the mean of fetishizing current middle-class social order. Avant-gardists' views of that time were full of ideological nebulosity and anarchism. They vehemently denied the contemporary bourgeois reality, rioted against the public, yet their ideals continued to be unshaped. One of their movement leaders, Edoardo Sanguinetti, proclaimed 
that the avant-garde rests on two main features - heroicpathetic and cynical, which, structurally and objectively, is the same [7]. Declaring that the avant-garde must not be dealt with just from the political positions and that aesthetical and psychological aspects must be factored in as well, Sanguinetti proposed to abandon the traditional aesthetical practices of the middle-class society on the way to new realism. Declaring himself Marxist, Sanguinetti was calling for the search of new content and new poetic diction.

In 1965, he took part in one of the discussions on the aesthetics of Tolstoy. Outlining the apparent significance of the Tolstoyan theoretical works, the avant-gardist focused the discussions on Tolstoy's realism. According to Sanguinetti, the marxist aesthetics cannot give a full and complete explanation to this "reactionary realism", wherein books' artistic sincerity is deeply authentic, in spite of their author's personal beliefs. Edoardo Sanguinetti assumes that Tolstoy had come to such realism owing to his "ideological disengagement", by abandoning the ruling class' official ideology and by accepting own independent view of life. That is why Sanguinetti suggests revising the concept of realism in reference to the work of Leo Tolstoy and substitute it with the expression "ideological realism", considering that such approach makes itself felt in Tolstoy's both philosophy and ideology.

The avant-gardist critic is ready to insist on the progressiveness and even revolutionism of the Tolstoyan teachings, which "enclosed truth under cover of Utopia". Moreover, Sanguinetti almost turns Tolstoy into the marxist: "In the manner often paradoxical, Tolstoy arrives at statements absolutely parallel with certain ideas of the Marxist philosophy." The reviewer enforces his thought with a citation from "Eros and Civilization" by Marcuse, who claims that the religion in a modern society is even more revolutionary than science, as the religion stands, though upside down, by certain revolutionary aspirations, which are often sold out by the corrupt science.

The Italian literary historian Albino Galvano also participated in the said discussions. He came up with quite convincing arguments regarding Tolstoy's role in modern age. Thus, Galvano made a good point of an odd coincidence between the theoretically opposite ideas of the aesthetics of Leo Tolstoy and Benedetto Croce. In spite that Croce had always advocated the autonomy of the art and Tolstoy by contrast fought for its high moral criteria and demanded rejection of the artistry's autonomy, according to Galvano, both theorists were broadly congruent with particular opinions: "Reading Tolstoyan slashing criticism of Baudelaire, Mallarme and decadents, I recalled how 20 years that passed after this Tolstoy's work, during the First World War Croce was condemning those admiring Rambo." [8]

Thinking about the treatise "What Is Art", Galvano points to "a biased approach" of the Tolstoyan analysis of Maupassant's writings, "Tolstoy somewhat frays his texts, accommodating own polemical objectives, with little respect even to the evident intent of the contents, and actually uses Maupassant as a sample of modern art to criticize this very art." If we saw just Tolstoy's bias and prejudice here, continues Galvano, then we would conclude that Tolstoy was, obviously, the great artist, yet a poor critic, which often happens with writers incapable of judging objectively. Nevertheless, one must also see that, on the other hand, Tolstoy has an exceptionally accurate, historical and relevant view of modern art, "It is difficult to find at the close of the $19^{\text {th }}$ century who could see with the same sharpness the destination of modern art. And such importance of Tolstoy as the critic has not been shaken by following works and experiences for sixty years that separate us from Tolstoy." And further, "Just as Tolstoy criticizes the art, which contributes to the disunion of people and has no ideals still living in folklore, indeed, he brings up a very pressing issue; in other words, Tolstoy ended in what presents the main problem for us all at present." Galvano completes his article with the following fair statement, "In spite of Tolstoy's inconsistencies, questioning and even inappropriateness of his opinions for us, it is this courage in conflict with himself, to the core, seems to me one of merits of Tolstoy as the critic, whose artistry we so deeply marvel at."

\section{CONCLUSION}

It should be concluded that the opinion of the Italian criticism was very much representative of the attitude to the Russian literary giant of the progressive and thinking part of Italian intellectuals of the second half of the $20^{\text {th }}$ century, seriously concerned about the decline in the modern national culture.

\section{REFERENCES}

[1] Eridano Bazzarelli, Come leggere oggi Tolstoi. Calendario del popolo, 1970. No. 305, p. 25562.

[2] Ibidem, p.2563

[3] History of Italy (three volumes). Vol. 2. M.: Nauka. P.31

[4] Cuzzer O. Leone Tolstoi. Roma. 1928

[5] L.N.Tolstoy. Complete edition. Vol. 60. P. 272

[6] Ibidem, P.231

[7] Edoardo Sanguinetti, Avanguardia e neoavanguardia. Milano, 1966, p.85.

[8] Albino Galvano, Arte e Morale. Marcatre, 1965, №11-13. 